\title{
Correction: High Prevalence of Anal Oncogenic Human Papillomavirus Infection in Young Men Who Have Sex with Men Living in Bamako, Mali
}

Donato Koyalta ${ }^{1,2^{*}}$, Ralph-Sydney Mboumba Bouassa ${ }^{3,4}$, Almoustapha Issiaka Maiga ${ }^{5}$, Aliou Balde ${ }^{6}$ Jules Bashi Bagendabanga ${ }^{7}$, Almahdy Ag Alinity ${ }^{8}$, David Veyer ${ }^{4}$, Hélène Péré ${ }^{4}$ and Laurent Bélec ${ }^{4}$

\section{Correction to: Infect Agents Cancer 16, 51 (2021) https://doi.org/10.1186/s13027-021-00385-0}

Following publication of the original article [1], the authors identified an error in the author name of Almoustapha Issiaka Maiga

- The incorrect author name is: Almoustapha Maiga

- The correct author name is: Almoustapha Issiaka Maiga

The author group has been updated above and the original article [1] has been corrected.

\author{
Author details \\ ${ }^{1}$ Centre Hospitalo-Universitaire Gabriel Touré, Bamako, Bamako, Mali. ${ }^{2}$ Faculté \\ des Sciences de la Santé Humaine de N'Djamena, N'Djamena, Chad. ${ }^{3} E c o l e$ \\ Doctorale Régionale en Infectiologie Tropicale, Franceville, Gabon. \\ ${ }^{4}$ Laboratoire de Virologie, Hôpital Européen Georges Pompidou, Assistance \\ Publique-Hôpitaux de Paris, and Université de Paris, Paris, France. \\ ${ }^{5}$ Laboratoire du Centre Hospitalo-Universitaire Gabriel Touré, Bamako, Mali. \\ ${ }^{6}$ Pierre Louis Institute of Epidemiology and Public Health (IPLESP), Sorbonne \\ University, INSERM, Paris, France. ${ }^{7}$ Project Linkages - Family Health \\ International, Bamako, Mali. ${ }^{8}$ Clinique Soutoura, Bamako, Mali.
}

Published online: 02 August 2021

Reference

1. Koyalta D, Mboumba Bouassa RS, Maiga A, et al. High Prevalence of Anal Oncogenic Human Papillomavirus Infection in Young Men Who Have Sex with Men Living in Bamako, Mali. Infect Agents Cancer. 2021;16:51. https:// doi.org/10.1186/s13027-021-00385-0.

The original article can be found online at https://doi.org/10.1186/s13027021-00385-0.

* Correspondence: koyaltad@yahoo.fr

${ }^{1}$ Centre Hospitalo-Universitaire Gabriel Touré, Bamako, Bamako, Mali

2Faculté des Sciences de la Santé Humaine de N'Djamena, N'Djamena, Chad

C C The Author(s). 2021 Open Access This article is licensed under a Creative Commons Attribution 4.0 International License, which permits use, sharing, adaptation, distribution and reproduction in any medium or format, as long as you give appropriate credit to the original author(s) and the source, provide a link to the Creative Commons licence, and indicate if changes were made. The images or other third party material in this article are included in the article's Creative Commons licence, unless indicated otherwise in a credit line to the material. If material is not included in the article's Creative Commons licence and your intended use is not permitted by statutory regulation or exceeds the permitted use, you will need to obtain permission directly from the copyright holder. To view a copy of this licence, visit http://creativecommons.org/licenses/by/4.0/ The Creative Commons Public Domain Dedication waiver (http://creativecommons.org/publicdomain/zero/1.0/) applies to the data made available in this article, unless otherwise stated in a credit line to the data. 